Turkish Online Journal of Qualitative Inquiry (TOJQI)

Volume 10, Issue 1, January 2019: 90-111

DOI: $10.17569 /$ tojqi.496012

Research Article

\title{
Information for Knowledge: A Case Study on Education Faculty Students' Internet-based Selective Learning Habits
}

\author{
Mehmet Ersoy ${ }^{1}$
}

\begin{abstract}
The purpose of this study is to scrutinize education faculty students' internet-based selective learning habits on a qualitative basis. A single-case holistic case study was conducted on an internet-based selective learning process following information retrieval. Participants were 37 sophomore students enrolled at three different departments of a state university in Turkey. Research data were collected in 2015 through observation records, field notes, participant diaries and interview questions. A four-week observation procedure was implemented in order to collect data on information search behavior and knowledge acquisition on the purpose of selective learning. Two stepwise-interviews were carried out based on typical sampling understandings: a co-constructed interview was conducted with the participants browsing only for information retrieval, using the data originated from the focus group interview on selective learning. Predisposition towards information retrieval and knowledge acquisition for selective learning were the two main themes derived from the data, and descriptive analysis was used to address these themes. The findings were interpreted in company with the subthemes-concepts structure and a series of implications were drawn based on the results of the study. The results of the study showed that a tendency to detailed search behavior is a threshold for selective learning. Participants with a tendency to learn selectively wanted to interact with the participants using online dictionaries and trying to conduct a specified search process. Although they were not given extra information about any criterion within the scope of the study, selective learners were capable of applying and discussing the search criteria (ie. whether a website cited any reference, the content credibility and usability) echoed by themselves. While being free to select the search topic in the field of study is an important motive for selective learning, being completely free for searching and reporting a topic does not work for both two groups. The study ends with some suggestions for future research, stakeholders and current practice.
\end{abstract}

Keywords: Learning habits, selective learning, information search behavior, information retrieval.

\footnotetext{
1 Asst.Prof.Dr., Eskişehir Osmangazi University, Faculty of Education, Department of Computer Education and Instructional Technology, mehmetersoy@ogu.edu.tr, https://orcid.org/0000-0002-0724-2825
}

Received: 12.12.2018 Accepted: 30.01.2019 


\title{
Bilgi İçin Enformasyon: Eğitim Fakültesi Öğrencilerinin İnternet Tabanlı Seçici Öğrenme Alışkanlıkları Üzerine Bir Durum Çalışması
}

\begin{abstract}
$\ddot{\mathbf{O z}}$
$\mathrm{Bu}$ araștırmanın amacı eğitim fakültesi öğrencilerinin internet tabanlı seçici öğrenme alışkanlıklarını nitel temelde derinlemesine incelemektir. Enformasyon edinimini izleyen bir internet tabanlı seçici öğrenme sürecini ele almak üzere bir bütüncül tek durum çalışması yürütülmüştür. 2015 yılında Türkiye'de bir devlet üniversitesinin ikinci sınıfında öğrenim görmekte olan ve üç farklı anabilim dalından 37 katılımcının yer aldığı araştırmanın veri kaynakları gözlem kayıtları, alan notları, katılımcı günlükleri ve görüşme sorularına verilen yanıtlardan oluşmaktadır. Dört haftalık bir sosyal gözlem ile enformasyon arayışı davranışı ve izleyen süreçte olası bir seçici öğrenme amaçlı bilgi edinimi konusunda veri toplanmıştır. Gözlemlerin ardından tipik durum örneklemesine uyan bir yordamla iki aşamalı görüşmeler gerçekleştirilmiş; seçici öğrenmeye yönelen katılımcılarla gerçekleştirilen odak grup görüşmesinden yararlanılarak enformasyon arayışı davranışı aşamasında kalan katılımcılarla işbirlikli yapılandırılmış görüşme gerçekleştirilmiştir. Enformasyon arayışı davranışı eğilimi ve seçici öğrenme amaçlı bilgi edinme, betimsel analiz süreçlerinin iki ana teması olarak ön plana çıkmıştır. Araştırmanın bulguları alttemalar ve işaret ettikleri kavramlar eşliğinde yorumlanmış ve bir dizi doğurguya dikkat çekilmiştir. Araştırmada detaylı arama yapmak isteğinin seçici öğrenmeye yönelmede bir eşik olduğu, enformasyon arayışı davranışından seçici öğrenmeye geçişte katılımcıların sözlük kullanan ve özelleşmiş arama yapmaya çalışan katılımcılarla etkileşim kurma eğilimi olduğu, doğrudan bir eğitim verilmese de seçici öğrenme eğiliminde olan katılımcıların kaynak aramada da kendilerince uygun gördükleri fakat aynı zamanda genel kabul gören kriterlere (Web sitesinin kaynak gösterip göstermediği, içeriğin kabul görüp göremeyeceği ve kullanılabilirlik) ulaşabildikleri sonuçları ortaya çıkmıştır. Aynı zamanda seçici öğrenmeye yönelmede alan kapsamında kalma koşuluyla konu seçiminde serbest bırakılmanın önemli bir etken olduğu sonucuna ulaş1llrken, konu seçiminde tamamen serbest olmak her iki grup için de iş görmemiştir. Çalışma araştırma alanı, paydaşlar ve güncel uygulamalara ilişkin önerilerle sonlandırılmıştır.
\end{abstract}

Anahtar sözcükler: Öğrenme alışkanlıkları, seçici ögrenme, enformasyon arama davranışı, enformasyon edinimi. 


\section{Introduction}

Retrieving information and transforming it for gathering knowledge have become the two most important issues in today's era of digital learning environments. Internet-based education accordingly, is a primary branch to meet the required skills for building a knowledge society. The Internet poses a paradox as it makes individuals receive instant, new but excessive amount of information. Thus, staying connected for a habitual learning is a critical issue in today's learning environments. Learning habits, directionally require a selective learning process for transforming information into knowledge.

Jones and Kohler (1958) were the first echoing selective learning as a concept of acceptable information. This understanding plays a strong role in criticizing the information and a possible following cognitive and constructivist philosophy. When considered with an opposite approach, a non-selective learning process can be addressed by behavioral aspects of learning. Hence, Garson (2006, p. 240) points out that classical conditioning is the most obvious example of non-selective learning. In 1940s the research field was mostly in conjunction with perception variable (Postman, Bruner \& McGinnies, 1948) and personal values and environmental factors were the basic concerns of interest. As a matter of fact, selective learning requires paradigmatic rationales for a behavior and its reflections as studied through the lenses of information retrieval and search behaviors in today's day and age. This paradigmatic motive leads researchers to shift between cognitive and constructivist perspectives, as compared in Table 1:

Table 1

Two Viewpoints for Selective Learning

\begin{tabular}{cccc}
\hline Cognitivist perspective (Weiss, 2012, p.2990) & Constructivist perspective \\
\hline$\bullet \quad \begin{array}{l}\text { memory span, immediate memory for word } \\
\text { lists. Not straightforward. }\end{array}$ & $\begin{array}{l}\text { ongoing interest in new understandings, } \\
\text { systems and organizations }\end{array}$ \\
\hline $\begin{array}{l}\text { the ability to suppress retrieval of less relevant } \\
\text { items }\end{array}$ & $\begin{array}{l}\text { respecting all kinds of information with a } \\
\text { literacy perspective, the ability to select } \\
\text { beneficial ones serving for knowledge } \\
\text { construction }\end{array}$ \\
\hline $\begin{array}{l}\text { incentive, or response to reward } \\
\text { metacognition, devising a strategy to remember } \\
\text { high-valued items to achieve a goal, not to } \\
\text { make a high score }\end{array}$ & $\begin{array}{l}\text { intrinsic motivation combined with social } \\
\text { contexts }\end{array}$ \\
\hline
\end{tabular}


As can be seen in Table 1, remembering, responding and memorizing are among the most distinct behaviors in cognitive-based selective learning process. In contrast, constructivist approaches provide a wide variety of applications for selective learning by centering an individualistic and alternative view, especially with Internet-based practices.

Internet-based selective learning (Ibsl), broadly refers to a self-paced, learner-centered and selfselective learning process, allowing experimentation in a safe environment, accommodation of different ability levels and types of learner, open access to information; reduced teaching costs, provision of reliable and timely help information, and reduced publication costs (Nunes \& Fowell, 1996). From Web users' perspective, three types of user query needs are identified (Manning, Raghavan \& Schütze, 2008) in an Ibsl process: Informational queries, the ones that this study targets, seek general information and users with informational queries typically try to assimilate information from multiple web pages. Navigational queries, seek the website or home page of a single entity that the user has in mind. Third, a transactional query is a prelude to the user performing a transaction on the Web, such as purchasing a product, downloading a file or making a reservation.

An important aspect of selective learning is separating information and knowledge and criticizing the reflections of both two concepts in a correct order. Figure-1 summarizes Ackoff's (1989) data-information-knowledge-wisdom (DIKW) hierarchy, which is a good example of this understanding:

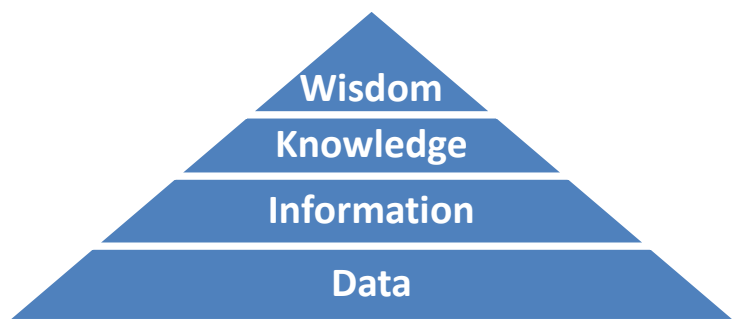

Figure 1. The DIKW hierarchy 
Bellinger (2004) adds understanding relations, patterns and principles which are described as the three main skills serving for Ackoff's (1989) hierarchy. On the other hand, Clark (2004) addresses five sub-skills for developing understandings that fit the hierarchy: researching, absorbing, doing, interacting and reflecting, respectively. Prior to Ackoff (1989), Zeleny(1987) uses the concept enlightment at the top of the hierarchy and reaching the sense of reality and right-wrong in a social context is assumed more important than wisdom. Reaching the wisdom is a problematic issue (Choo, 2001) and the rest of the phases in the hierarchy may contain some kind of anti-structure. At this point, Bernstein (2011) draws attention to an anti-thesis and uses misinformation, disinformation and error against Information, and ignorance for Knowledge. In fact, these anti-concepts become contaminative for learning, especially in Internet-based social contexts.

DIKW hierarchy also provides a comprehensive background for the concepts of knowledge economy and knowledge ecology. Today developmental rate of the societies is highly associated with the quality of the relations between information and knowledge. In this sense, information retrieval and using technology for knowledge acquisition play an important role in reconceptualization of learning. Technology may be described as a learning catalyst in this process.

Background knowledge on information retrieval is an important component of learning process and studied since early stages of the research efforts on learning habits. While Fidel (1991) pointed out that subject knowledge affected only experienced searchers, Hsieh-Yee (1993) found out that searchers use more of their own terms in searching a topic they knew about. It seems that both two approaches function as a symbiotic pair in today's world of multitasking. As a matter of fact, being knowledgeable about the content or a task is an important factor for selective learning. There are recent studies on the issue and some of them are not subject to Internet. McDonald and Ma (2015) conducted a study on 4 and 6 year-old children's knowledge attribution and selective learning. The study contains two sub-studies and first study seeks a choice between formally and casual dressed person in terms of knowledge potential. On the other hand, the second study is realized with the same characters and seeks different behaviors while getting help about a learning task. Results show that participants find formally dressed individuals more 
knowledgeable and choose them while getting help about the task. Reliability of the information on the Internet has similarities with the study and if meaningful criteria are met, then it is acceptable information for the users and learners. Another study on selective learning was conducted by Henderson, Sabbagh and Woodward (2012), which focuses on the relevance principle in preschoolers' selective learning. The study seeks a link between 4 year-olds' word learning and their everyday communicative contexts. The speakers' and objects' presence is a factor to evaluate for selective learning and results show that participants' selective learning is attuned to relevance, and an overarching principle of prospective relevance.

The literature on selective learning on the Internet highly associates with information seeking and also different learner and searcher characteristics. Zhou (2013) conducted a study on twelve male Chinese university students' different activities during online search and found that high performance level-participants formulate a strategy and adapt it through different search tasks. Most of the participants begin to search more in detail when they read the content carefully and noted the key terms. Moreover, high performance group did bring their prior knowledge or paraphrase the information into a meaningful answer. Low performance group could not synthesize information effectively. Another study which was conducted by Al-Suqri (2011) emphasizes on information-seeking behaviors of 50 social science scholars and originated some main and sub-themes on the issue. The study did not categorize the users on high or low performance. According to the results, main themes vary on awareness of resources (sub themes: print-electronic and other types, may be considered as associated concepts), implications of being unable to find resources (feeling and actions), other barriers to effective research (IT-related, time related), initiation (consideration, preparation and expectations), exploration (prioritization of sources, informal-formal sources, familiarity and knowledge, keyword search and overcoming barriers), shifting (extracting, revisiting), resources selection (judge, quality, validity, wellknown). Search strategies and problems are among the most encountered issues raised during Internet-based information seeking. In a study conducted by Kabakci et al. (2010), 21 elementary school teachers' search strategies were investigated and three common strategies came to the fore: using operators and commands, keyword search and subject specific websites at the beginning of the searching process. Some of the teachers complained about the lack of the Turkish resources, and the other problems echoed were irrelevant or insufficient information and 
accessing the resources (ie. membership, virus). Apart from these individualistic realities, some research understandings focus on collaborative information seeking. Hyldegard (2009) touches upon individuals and group members' information behaviors during an Internet-based search in specific tasks. Participants are 10 graduate students and demographic surveys, process surveys, diaries and interviews were used. The results show that similarities in behavior were found between group work and individualistic work, a similar interest to learn selectively between these two approaches was found at the beginning of the activities. As searching activities were increased, an interest to writing activities were increased and the study reported that complex problem solving activities seemed to be more complex in a group work setting.

Internet plays an important role in today's knowledge-based systems. An intensive and predominantly discourse-centered information is transferred into new information, and also knowledge. Hence, a fast and elusive process for learners of this new era requires specified skills. Skills for retrieving and transferring information into knowledge are important for both students, and teachers who train the individuals and directionally build future jobs. An education faculty can be described as a minimal example of knowledge society, and a broad range of research understandings can come to the fore while discovering the possibilities for Internet-based practices.

\section{Purpose of the study}

The purpose of this study is to conduct an in-depth analysis of education faculty students' Internet-based selective learning habits. The study also purposes to approach behavioral aspects of Internet-based selective learning for gathering knowledge. The following research questions were considered to address the purpose of the study:

1. Which behavioral characteristics do the participants have when searching about a contentspecific topic on the Internet?

2. What views do the participants of Information Retrieval (IR) Group have about the factors causing them not being able to focus on selective learning? 
3. What views do the participants of Selective Learning (SL) Group have about the factors ensuring selective learning for gathering knowledge?

\section{Methodology}

\section{Research paradigm}

The research is designed as a single-case holistic case study (Yin, 2009), and has a descriptive nature. With a single-case study, researchers look for an average case; a case that is a typical example of a specific phenomenon (Mills, Durepos \& Wiebe, 2010, p.61). As a matter of fact, researcher subjectivity and rigor are two important limitations of case study design. To balance rigor and relevance, I added participants from different departments of an education faculty into sampling and collected data with the help of independent observers, asked participants to keep diaries and used field notes for enhancing data triangulation. A field expert also analyzed the data and thematic coherence was validated.

Many opportunities and possibilities may gain currency for case studies. The march of observed events mostly leads researchers to conduct focus group, structured, semi-structured or even costructured interviews. On the other hand, voluntariness and sustainable observation are among the most important challenges of case study procedure, which was introduced in the following sections.

\section{Context and participants}

The study focused on higher education and faculties functioning for teacher education. Since content knowledge is an essential part of teacher competencies, searching for a possible selective learning is directionally centered, and behavioral characteristics, choices and tendencies were addressed within the context of the study. Participants were 37 sophomore students of a state university, from Special Education $(\mathrm{n}=12)$, Psychological Counselling and Guidance $(\mathrm{n}=12)$, and Mathematics Education $(n=13)$ departments and aged between 19 and 21. They were volunteer 
participants and a written statement including the rationale for the study and video recordings was provided to them. Their identity remained confidential throughout the research process.

\section{The case}

This study mainly focuses on the possibilities following information search behavior, especially when students encounter a choice between using information for only filling the blanks of a design or homework and using it also for knowledge acquisition. The case within the scope of the study is the choice between information retrieval and knowledge acquisition. Students occasionally transfer information from Internet to an offline platform (ie. presentation softwares and/or literature reports) for definitional information. In this case, some students use information temporarily and therefore may break a link for learning, while some deal with it, showing signs of a connectivist perspective. It is accordingly important to reflect their experiences and follow the searching behavior for a possible selective learning habit in repetitive Internet-based practices.

In the study, the process of Internet-based practice consisted of activities related to contentspecific topics in participants' field of study, and also different fields. Participants were to follow basic instructions of each activity (how to search, summarize and interpret) and write a reflection discussing the topic. As selective learning's nature offers, they were free to select any topic. Each activity lasted one hour and there were a total of 12 activities in four weeks' time. The case was viewed in a mostly taxonomic structure including various skills which can be listed as follows: Apply, analyze, evaluate, create, characterizing, organizing, valuing and responding which were assigned to different weeks. The instructions were quite flexible and a participant was free to google or search in social networks, blogs, Wikis or video lectures. Ethical issues were considered and a handout was provided to participants at the beginning of the research process. 


\section{Instruments, data collection and analysis}

The study used various instruments for observing and interviewing the participants. Figure 2 depicts the research process which started with developing observation criteria and finished with determining sub-themes and concepts:

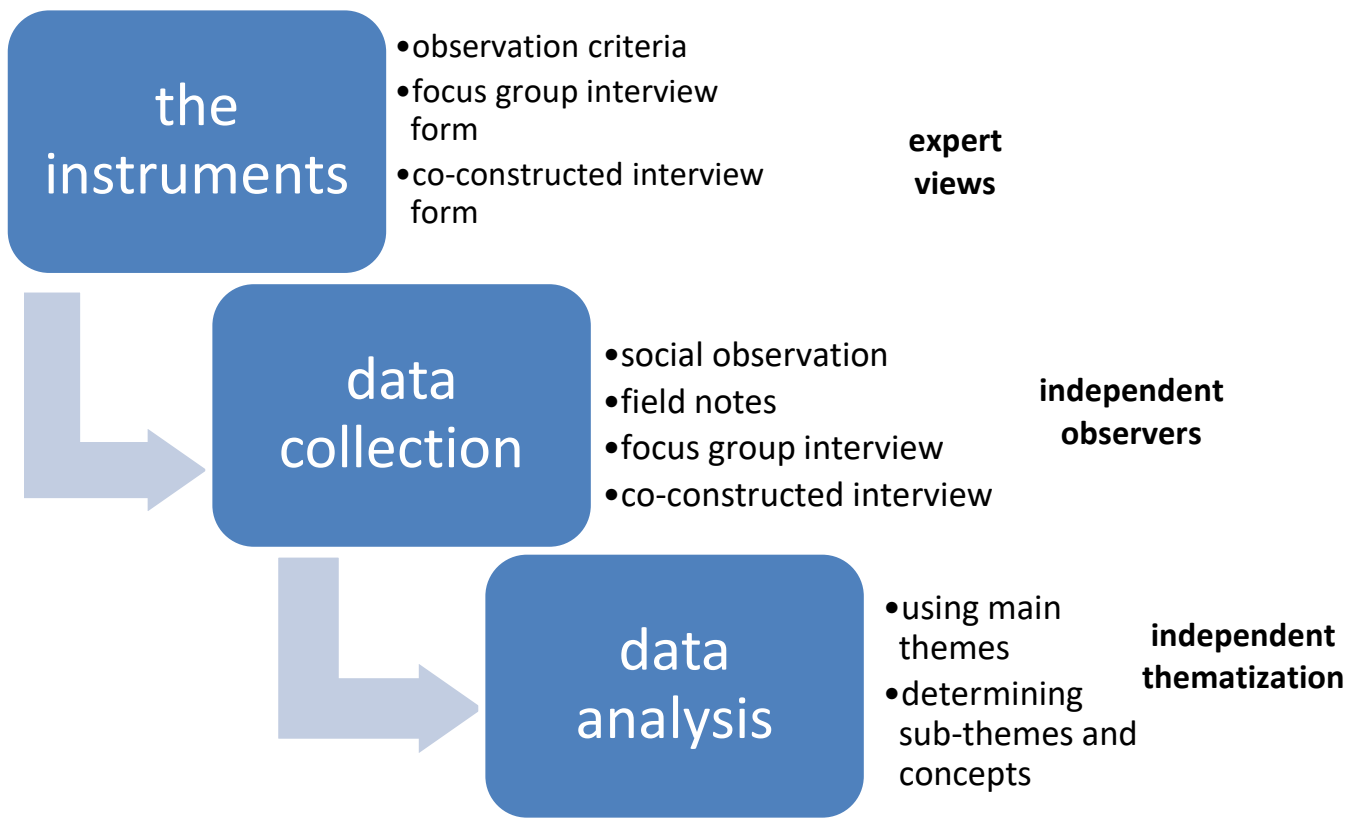

Figure 2. Research process

A four week-social observation procedure was conducted by two independent observers within the scope of the study. The observations were realized through the following criteria by using checklists, seeking whether a participant:

- conducts a detailed search for a content-specific topic?

- uses more than one search engine?

- $\quad$ uses time effectively?

- $\quad$ gives up searching early?

- $\quad$ read the specific information about the concepts of his/her field of study carefully?

- cites only definitional information? 
- $\quad$ cites detailed explanations?

- $\quad$ adds views and plausible comments?

- $\quad$ adds new definitions, syntheses and evaluations?

Two video cameras were used throughout the observations, and in this way internet search behaviors could be viewed in detail on the basis of gesture-facial expression, and also browsing the Internet from both two sides. The participants completed diaries for each week of the research process, and I took field notes in order to reflect the nature of the phenomenon. This approach is quite beneficial as it depicts the case both from the participants and the researcher perspective.

Before jumping into the process of coding data, as Stuckey (2015) noted by stating "It is important to think about your research question and the big picture, which some may refer to as "storyline" or "meta-narrative".", this study directionally followed a similar approach and behavioral characteristics of the participants conducting a research on the Internet and their story through a possible selective learning process was centered. A focus group interview was conducted with SL Group and interview findings were used for constructing the second interview for IR Group. This alternative approach is called co-constructed interview and was echoed by Miller (2011).The rationale for conducting such a methodology is that selective learners' data were quite beneficial for organizing a descriptive structure for IR Group's interview.In brief, data originated from SL Group became main themes for interviewing IR Group. Thematization work included using the same coding strategy for both two interviews: The most common themes ran for sub-themes originated from interviews, field notes and diaries. The nature of the study required a descriptive manner for analyzing research data, since two main themes came to the fore: searching for information (information retrieval) and knowledge acquisition for selective learning. An independent expert analyzed the raw data (video analyses included) and two thematic analyses found to be similar with a 88 per cent coherence, as Miles and Huberman (1994) suggested with reliability=consensus/consensus +dissidence formula. The expert was also asked to name each sub-theme and we finally came up to 82 per cent coherence with the thematization. 


\section{Results}

The results can be reviewed under three main sections: behavioral characteristics of the participants, browsing the Internet for information retrieval and the case of knowledge acquisition for selective learning, respectively. The realities which themes motive were interpreted and participants' quotes included where necessary.

\section{Behavioral characteristics of the participants}

The video analyses of the first two weeks' observation procedure revealed that most of the participants did not conduct a detailed search and the number of participants using more than one search engine did not increase weekly. This may not be directly interpreted with a selective learning perspective, because most of the participants tended to search in their own language and in fact the literature in Turkish is quite definitional. There were 22 participants who tried to retrieve more and went towards selective learning process. This problem led them to seek for a more detailed content and some were eager to learn selectively at the beginning of the activities, while some tended to accommodate to the knowledge acquisition due to this problem. On the other side last two weeks' lists showed that participants used online dictionaries and encyclopedias. Participants prefer using translated content, in other words they prefer translators against using online dictionaries. This poses a problem for participants while transferring information into knowledge, and some of them pointed out it in their diaries. Participant 1-D complained about the amount of the resources in English and enounced that he can find limited time to interpret because of translation. On the other hand, participants dealing with an additional translation work make valuable interpretations on the content they collected. In the forthcoming weeks, the group of participants who helped each other looking up words in dictionaries tended to study on their own, and tried to learn the basics for selective learning willingly.

A general look from the viewpoint of gesture-facial expression, both two groups were interested in the process at the beginning of the activities, while SL group took an eager interest in last two weeks' activities. Their gesture and facial expression gave the observers an impression that they enjoy the activities. According to the front camera records, in IR Group when two weeks passed 
there was an obvious interest to the participants using dictionaries. Some participants stood up and wondered which sources they were browsing, while others worked on their own, for the rest of the process.

\section{Browsing the Internet for information retrieval}

A co-constructed interview was conducted with the participants of the IR Group. Table 2 summarizes the results of the interview, which were interpreted accompanying field notes and diaries:

Table 2.

Interview Results of the Information Search Behavior

\begin{tabular}{|c|c|c|}
\hline Theme & Sub-theme & Concept \\
\hline \multirow{6}{*}{ Searching for information } & $\begin{array}{l}\text { Availability of the resources } \\
\text {-the length of definitional information } \\
\text {-author's expertise }\end{array}$ & $\begin{array}{ll}- & \text { citation } \\
\text { - } & \text { field expertise } \\
\text { - } & \text { trustworthiness }\end{array}$ \\
\hline & $\begin{array}{l}\text { A specific effort for searching } \\
\text {-in search of detailed information } \\
\text {-reading the whole content } \\
\text {-taking notes }\end{array}$ & $\begin{array}{ll}\text { - } & \text { self-study method } \\
\text { - } & \text { learning task }\end{array}$ \\
\hline & $\begin{array}{l}\text { Reasons for not conducting a detailed } \\
\text { search and the rationale for not going } \\
\text { towards selective learning } \\
\text {-finding the content enough for } \\
\text { learning tasks } \\
\text {-finding the work enough for } \\
\text { finishing the work (for presentation or a } \\
\text { literature report) } \\
\text {-being unfamiliar with the field }\end{array}$ & $\begin{array}{ll}\text { - } & \text { motivation } \\
\text { - } & \text { experience } \\
\text { - } & \text { evaluation } \\
\text { - } & \text { content development }\end{array}$ \\
\hline & $\begin{array}{l}\text { Factors for not going towards selective } \\
\text { learning process } \\
\text {-unwillingness to search for }\end{array}$ & $\begin{array}{ll}\text { - } & \text { motivation } \\
\text { - } & \text { self-confidence } \\
\text { - } & \text { self-efficacy }\end{array}$ \\
\hline & $\begin{array}{l}\text { detailed information } \\
\text {-spending most of the time with } \\
\text { design issues (presentation } \\
\text { and/or report) }\end{array}$ & $\begin{array}{ll}\text { - } & \text { design } \\
\text { - } & \text { continuing education } \\
\text { - } & \text { literacy }\end{array}$ \\
\hline & $\begin{array}{l}\text { Prerequisites for selective learning } \\
\text {-tutorial support for a detailed } \\
\text { search } \\
\text {-digital enhancement for sources } \\
\text { in Turkish } \\
\text {-changing the method for } \\
\text { concept learning }\end{array}$ & $\begin{array}{ll}\text { - } & \text { social learning } \\
\text { - } & \text { coaching } \\
\text { - } & \text { literature } \\
\text { - } & \text { concept teaching } \\
\text { - } & \text { concept learning }\end{array}$ \\
\hline
\end{tabular}


As summarized in Table 2, IR Group focuses on suitable citations, field expertise (about themselves) and trustworthiness rather than didactic usability or a possible learning process. They are in a mood that a continuing motivation for a learning process is a bit far away and find their experience not enough for interpreting the content. They therefore need assistance for a detailed search and at least a social learning environment. This may be quite beneficial for getting experience from others; however individualistic approaches are also required since Internet-based content search functions mostly on an individualistic basis both in school settings and also everyday life. Some participants point out this in line with continuing education, and it can be said that they are aware of the future needs about the content on the Internet, which is not a generalizable finding.

Field notes related to IR Group report two different categories of searchers at the end of first two weeks: The ones who gave up searching in very early stages of the activities, focused on designing and saving the final document, and the second sub-group who were interested in other participants' work and tried to learn from them. The last two weeks notes were not something new for the first sub-group, but pointed out that most of the second sub-group's participants began to deal with searching tasks and interpretation parts of the activities.

IR Group had a background on detailed and specified search according to the Observation Criteria List. However the group was not disposed to prepare a detailed document on the topic they were searching, and also benefiting from it. Some participants of this group were interested in other participants' work and evaluated the content in a critical approach. Since the study was not conducted within the scope of a course, some of them felt free about the work and also reflected this convenience in their diaries. Participant 18-D noted this by stating "I would not normally continue with this work, but being free while studying was enjoying and this kept me to interact with others. This was cool, and I will do the next ones.”. Moreover, another participant points out an important aspect of using only definitional information: "I am confident with the definition, but when I tried to interpret it there was something missing: How will I do that? (Underlines this question in the diary)". In fact, this raises a question about concept learning: Do students learn to make critics on concepts? Participants who found also interpretations or comments in their collection were beginning to notice that this is an essential part of going 
towards learning, and also a challenge. During the last two weeks, the participants who are aware of different types of content, making critics and choosing to deal with the content with this approach were added to SL Group.

\section{The case of knowledge acquisition for selective learning}

The case within the scope of the study was realized through a focus group interview with the participants of SL Group, in company with field notes and diaries. A theme, sub-theme and concept structure was followed as it used to be in previous interview findings, which can be reviewed in Table 3:

\section{Table 3.}

Interview Results of the Selective Learning Process

\begin{tabular}{|c|c|c|}
\hline Theme & Sub-theme & Concept \\
\hline \multirow{4}{*}{$\begin{array}{l}\text { Knowledge acquisition for } \\
\text { selective learning }\end{array}$} & $\begin{array}{l}\text { The strengths and weaknesses of } \\
\text { Internet-based searches } \\
\text {-finding more information than hard- } \\
\text { copy forms } \\
\text {-getting lost in the information } \\
\text { overflow } \\
\text {-seeking proprietary information } \\
\text { for gathering knowledge } \\
\text {-waste of time } \\
\text {-openness to share knowledge }\end{array}$ & $\begin{array}{ll}- & \text { information seeking } \\
\text { - } & \text { time } \\
\text { - } & \text { source } \\
\text { - } & \text { openness }\end{array}$ \\
\hline & $\begin{array}{l}\text { Search strategies (in the field of study) } \\
\text {-searching for definitional knowledge } \\
\text {-expanding the search strategies } \\
\text {-listing the basic headings and } \\
\text { re-searching } \\
\text {-studying on the results and learning } \\
\text { the content }\end{array}$ & $\begin{array}{ll}\text { - } & \text { definition(concept learning) } \\
\text { - } & \text { web redirection } \\
\text { - } & \text { search strategy } \\
\text { - } & \text { self-study method }\end{array}$ \\
\hline & $\begin{array}{l}\text { Search strategies (in different fields of } \\
\text { education) } \\
\text {-following the same strategies } \\
\text {-using social networks and } \\
\text { participating in discussions }\end{array}$ & $\begin{array}{ll}\text { - } & \text { self-study method } \\
\text { - } & \text { search strategy } \\
\text { - } & \text { web redirection } \\
\text { - } & \text { social networks } \\
\text { - } & \text { social network literacy } \\
\text { - } & \text { social learning } \\
\end{array}$ \\
\hline & $\begin{array}{l}\text { Motivational factors for selective } \\
\text { learning } \\
\text {-dissatisfaction with the content } \\
\text {-a particular tendency to search for } \\
\text { detailed information according the } \\
\text { previous experiences } \\
\text {-ongoing curiosity about the titles in } \\
\text { the webpage }\end{array}$ & $\begin{array}{ll}\text { - } & \text { interests } \\
\text { - } & \text { curiosity } \\
\text { - } & \text { experience } \\
\text { - } & \text { expertise } \\
\text { - } & \text { critical thinking }\end{array}$ \\
\hline
\end{tabular}




\begin{tabular}{|c|c|c|}
\hline Theme & Sub-theme & Concept \\
\hline \multirow{3}{*}{$\begin{array}{l}\text { Knowledge acquisition for } \\
\text { selective learning }\end{array}$} & $\begin{array}{l}\text { Realizing the value of web search } \\
\text { behavior for learning } \\
\text {-area of interest } \\
\text {-transferring knowledge for future } \\
\text { learning tasks } \\
\text {-expertise in discussions and } \\
\text { interpretive strategies }\end{array}$ & $\begin{array}{ll}\text { - } & \text { evaluation } \\
\text { - } & \text { expertise } \\
\text { - } & \text { learning material } \\
\text { - } & \text { literacy }\end{array}$ \\
\hline & $\begin{array}{l}\text { Making detailed search a habit for } \\
\text { selective learning } \\
\text {-applied courses } \\
\text {-following up-to-date websites } \\
\text {-The type of the websites (static } \\
\text { websites, discussion forums, groups or } \\
\text { pages in SNSs) }\end{array}$ & $\begin{array}{ll} & \text { actuality } \\
\text { - } & \text { website evaluation criteria }\end{array}$ \\
\hline & $\begin{array}{l}\text { Factors for a possible future tendency } \\
\text { of selective learning } \\
\text {-ongoing experience } \\
\text {-foreign language acquisition } \\
\text {-increase in applied activities }\end{array}$ & $\begin{array}{ll}\text { - } & \text { foreign language } \\
\text { development } \\
\text { - } & \text { experience } \\
\text { - } & \text { habit }\end{array}$ \\
\hline
\end{tabular}

SNS: Social Networking Site

As can be seen in Table 3, participants of SL Group are aware of strengths and weaknesses of Internet-based searches. They find the Internet as an opportunity for information seeking, and spending quality time on the Internet opens the gate for gathering knowledge according to their comments. Discussions on the Internet provide valuable content to them. Moreover, they do not let well enough alone and run a self-study process in a habitual manner.

Participants of this group made an impression that was quite different from IR Group in terms of defining concepts on their own, analyzing and mining the valuable content in order to suggest sub-concepts. A more preponderating emphasis on self-study method was echoed by this group. An obvious tendency for selective learning from the beginning of the activities was highly associated with working independently. They pointed out that this was a habit for a long time, and would be long-lasting for future works on search behavior. The reason and motive for such a tendency was enounced as curiosity and seeking for up to date content which is not droning in order not to lose actuality. In brief, as summarized on concepts in Table 3 selective learning tendency was triggered by an arousing interest with current ways of knowledge acquisition, and also valuing and criticizing each part of the content. Field notes for this group mainly reported a high motivation for the activities and participants coming from second sub-group of IR Group who showed similar performance with natural members of this group were quite successful 
during the activities. Participants give importance not only to content, but also knowledge acquisition process. These experiences turn into a selective learning habit and come to the fore with repetitious works. Participant 6-G pointed out this by stating "First I looked for the concepts, and tried to interpret them. Then I visited independent forums and Facebook groups for discussions. But these were only for copying content. So I tried to make interpretations. For example you asked us to write a story about a psychological disorder. I began to imagine possible dialogues with patients using the content in both definitions and also forums-Facebook (participants mostly used Facebook groups for learning the disorders in detail)." Similarly Participant 2-F noted websites' importance in selective learning by stating "I was curious about the titles in an activity. When I tried to search for the most important ones, I found another website and begin to warn myself. I should have produced a document. Then I summarized each website's examples on derivative and finally could find geometric interpretation of derivative". It is quite apprehensible that selective learners were motived by organizing knowledge on their own way, and soon building a new content with their own understandings.

\section{Discussion}

There are a good number of findings that can be discussed about the current study. IR Group's search behaviors after finding the source mostly center upon reading the full content and taking notes, and these behaviors lead them not to think about the source, its originality, trustworthiness and authors' expertise. They just copy the content and use the Internet as a bridge for completing a task, not for learning. These behavioral processes may be discussed in terms of being knowledgeable about searching a topic, but with a lack of knowledge about its functions about future learning contexts. In some contexts, this may be ascribed to individuals' motivation -as they enounced during the interviews- but another factor is may be a more determinant one: a specific effort for self-efficacy. Selective learners seem already prepared for these processes and they made their choice between information and knowledge not only in this study, but also when they realized this as a general experience that must be acquired for every learning task. 
SL Group's awareness about devising the searched content gets along with Zhou's (2013) study that high performance level participants formulate a strategy even they were not given any instruction. The reason for paralleling the two studies can be confined to the both two group participants' willingness for using a selective learning strategy for future tasks.

Time is another common factor for not getting through selective learning process as Al-Suqri (2011) found. Similar findings were found and participants state that while searching a topic, spending too much time enounced as a problem. Kabakci et al. (2010) point out an associated issue about time, and a lack of Turkish sources made participants have problems in finding time for interpreting the sources in English, which was found also in the current study. In contrast with the current study's finding about the group work's benefits on IR Group, Hyldegard (2009) found complex problem solving activities seemed to be more complex in a group work setting. When considering that the current study was not organized within the scope of a collaborative research setting, and that especially IR Group's participants grew a natural interest to group work, this finding may partly conflict with Hyldegard's (2009) study.

\section{Conclusion and recommendations}

Education faculties not only deal with content-based procedures, but also focus on pedagogydriven approaches. Pedagogical approaches require staying up to date, since building a knowledge society highly associates with training prospective teachers as selective learners. Although this study did not focus on competencies of teaching profession, especially selective learners' views about future give a positive impression about their potential.

In light of the numerous findings of this study, it is understood that the tendency to a detailed search behavior is a threshold for selective learning. Participants' views show another crucial reality: Apart from homeworks or exams, independent activities which promote specific search behaviors open the gate for habitual learning, and the learner soon enter selective learning process. Some of the participants tended to interact with others while searching, and this finding leads to an understanding that personalized learning activities should be revised in today's world 
of collaboration. Making participants feel free to collaborate with others resulted a favorable impression, especially for IR Group without an organized process of the study. Studying in their field of study, participants who freed from topic choice were more eager to learn selectively. However, the interest in proceeding to selective learning could not be same for the participants who were totally free in both two groups. Field dependence was a quite important issue in getting towards selective learning. Besides, participants of both two groups preferred social networks and/or forums for searching an unfamiliar topic. Independently of being a selective learner or not, this result may be another matter of debate for social factors in information retrieval and can be subject of a future research agenda.

The study can be organized in a totally online platform, and choices of information retrieval can be viewed in a different context. Moreover, information search behavior can be revisited in a collaborative manner for investigating the possible reflections of social learning. Teachers and educators can be added to data collection in a more detailed case. For multiple environments (Mobil-lab or print-Web, especially for context dependence), comparative studies can be modeled. In addition to these suggestions, qualitative paradigm may be related to psychosocial variables within the context of mixed-method inquiries. It is thought that applied research on selective learning is truly important for both learning, and diversification of content on the Internet. In this regard, an activity-based and step-by-step practical mechanism originated from this research area will be quite beneficial for transferring information into knowledge. 


\section{References}

Ackoff, R.L. (1989). From data to wisdom. Journal of Applied Systems Analysis, 16, 3-9.

Al-Suqri, M.N. (2011). Information-seeking behavior of social science scholars in developing countries: A proposed model. The International Information \& Library Review, 43, 1-14.

Bandura, A. (1982). Self-efficacy mechanism in human agency. American Psychologist, 37, 122147.

Bellinger, G., Castro, D., \& Mills, A. (2004). Data, information, knowledge, wisdom. Retrieved July, 22, 2018, from http://www.systems-thinking.org/dikw/dikw.htm

Bernstein, J.H. (2011). The data-information-knowledge-wisdom hierarchy and its antithesis. NASKO, 2(1), 68-75

Choo, C.W. (2001). The knowing organization as learning organization. Education+Training, 43(4), 197-205.

Clark, D. (2004). Understanding and performance. Retrieved July, 20, 2018, from http://www.nwlink.com/ donclark/performance/understanding.html

Fidel, R. (1991). Searchers' selection of search keys: I. The selection routine. II. Controlled vocabulary or free-text searching. III. Searching styles. Journal of the American Society for Information Science, 42, 490-527.

Garson, J.R. (2006). Psychiatric disorders and biological dysfunctions: Some philosophical questions concerning psychiatry. Unpublished Doctoral Thesis. Graduate School of the University of Texas, ATX.

Jones, E.E., \& Kohler, R. (1958). The effects of plausibility on the learning of controversial statements. Journal of Abnormal and Social Psychology, 57, 315-320.

Henderson, A.M.E., Sabbagh, M.A., \& Woodward, A.L. (2012). Preschoolers' selective learning is guided by the principle of relevance. Cognition. doi: 10.1016/j.cognition.2012.10.006 
Hsiyeh-Yee, I. (1993). Effects of search experience and subject knowledge on the search tactics of novice and experienced searchers. Journal of the American Society for Information Science, 44(3), 161-174.

Hyldegard, J. (2009). Beyond the search process-Exploring group members' information behavior in context. Information Processing and Management, 45, 142-158.

Kabakci, I., Firat, M., İzmirli, S., \& Kuzu, E.B. (2010). Opinions of Teachers on Using Internet Searching Strategies: An Elementary School Case in Turkey. Turkish Online Journal Of Qualitative Inquiry, 1(1), 49-61.

Manning, C., Raghavan, P., \& Schütze, H. (2008). Web search basics. In Introduction to Information Retrieval (pp. 385-404). Cambridge: Cambridge University Press. doi:10.1017/CBO9780511809071.020

McDonald, K.P., \& Lili, M. (2015) Dress nicer=know more? Young children's knowledge attribution and selective learning based on how others dress. PLOS ONE, 10(12).

Miles, M.B., \& Huberman, A.M. (1994). Qualitative data analysis: A sourcebook. Beverly Hills: Sage.

Miller, E. (2011). Indeterminacy and interview research: Co-constructing ambiguity and clarity in interviews with an adult learner of English. Applied Linguistics, 32(1), 43-59.

Mills, A.J., Durepos, G., \& Wiebe, E. (2010). Encyclopedia of case study research. London: Sage.

Nunes, J.M., \& Fowell, S.P. (1996). Developing educational hypermedia applications: a methodological approach. Information Research, 2(2). Retrieved on March 27, 2014 from http://www.informationr.net/ir/2-2/paper15.html

Postman, L., Bruner, J.S., \& McGinnies, E. (1948). Personal values as selective factors in perception. Journal Of Abnormal and Social Psychology,43, 148-153.

Stuckey, H.L. (2015). The second step in data analysis: Coding qualitative research data. Journal of Social Health Diabetes, 3, 7-10.

Weiss, S.J. (2012). Selective associations. In (Ed.), Encyclopedia of the sciences of learning (pp. 2983-2987). NY: Springer. 
Information for Knowledge: A Case Study on Education Faculty Students' Internet-based Selective Learning Habits

Yin, R.K. (2009). Case study research: design and methods (4th Ed.). Thousand Oaks, CA: Sage

Zeleny, M. (1987). Management support systems: towards integrated knowledge management. Human Systems Management, 7(1), 59-70.

Zhou, M. (2013). A Systematic Understanding of Successful Web Searches in Information-based Tasks. Educational Technology\& Society, 16(1), 321-331. 